\title{
Large-scale production and purification of recombinant protein from an insect cell/baculovirus system in Erlenmeyer flasks: application to the chicken poly(ADP-ribose) polymerase catalytic domain
}

E.A. Miranda,

G. de-Murcia and

J. Ménissier-de-Murcia

\author{
Ecole Supérieure de Biotechnologie de Strasbourg, UPR 9003 du CNRS, \\ Cancérogenèse et Mutagenèse Moléculaire et Structurale, \\ 67400 Illkirch-Graffenstaden, France
}

Correspondence

E.A. Miranda

Bioprocess Engineering Laboratory

Faculdade de Engenharia Química

Universidade Estadual de Campinas

Caixa Postal 6066

13093-970 Campinas, SP

Brasil

Fax: 55 (019) 239-4717

E-mail: everson@feq.unicamp.br

Research supported by the Ligue Nationale Contre le Cancer and by the Association pour la Recherche Contre le Cancer.

Received July 30, 1996 Accepted June 11, 1997

\begin{abstract}
A simple and inexpensive shaker/Erlenmeyer flask system for largescale cultivation of insect cells is described and compared to a commercial spinner system. On the basis of maximum cell density, average population doubling time and overproduction of recombinant protein, a better result was obtained with a simpler and less expensive
\end{abstract} Key words - PARP

- Insect cells

- Baculovirus

- Overproduction lar response to DNA damage $(3,4)$. PARP is a highly conserved enzyme consisting of three main functional modules: a 46-kDa N-terminal DNA-binding domain bearing the nickdetection and the nuclear localization functions, a central 22-kDa polypeptide fragment containing the automodification sites and a C-terminal fragment of $40 \mathrm{kDa}$ containing all the catalytic activities usually associated with the full-length enzyme (for a review, see 5).

Since PARP is a potential target in cancer chemo- and radiotherapy (for a review, see 6), there was a need to know the threedimensional structure of PARP and particularly its catalytic domain to generate new specific inhibitors. In turn, production of large quantities of fully active recombinant 
polypeptide necessary for crystallization experiments required an appropriate expression system. In our attempts to overproduce the full-length PARP protein (7) or any of its functional domains $(4,8)$ we have learned that the most appropriate system was, by far, the insect cell/baculovirus expression vector (IC/BEVS). However, despite substantial efforts to improve the engineering aspects of cell cultivation and protein production scaleup (9-14), large-scale protein production by IC/BEVS at the bench level has always posed a problem for researchers wishing to utilize this powerful expression system. In order to produce milligram amounts of protein, a few liters of cell culture must be prepared and a large number of culture flasks, expensive bottles or bioreactors, items not common in many laboratories, must be employed. In our laboratory, after discarding the use of culture flasks to grow insect cells, we tried to use spinner flasks. Despite the use of different protocols, results were unsatisfactory regarding final cell density, volume of cell culture, and growth rate. Since Neutra et al. (15) have recently indicated that the IC/ BEVS can be efficiently run in shaker flasks, we implemented a bioreactor system similar to that described by Neutra and co-workers which was simpler and could be used on a larger scale. This system proved to be efficient, easy to run, and inexpensive, and the results obtained were superior to those observed using spinner flasks. In the present study we describe this system and the protocol we routinely use for large-scale production of the chicken poly(ADP-ribose) polymerase catalytic domain and its purification.

\section{Material and Methods}

\section{Cell stock and medium}

Spodoptera frugiperda cells (Sf9 cells) were grown at $27^{\circ} \mathrm{C}$ in TNM-FH medium (Sigma Chemical Co., St. Louis, MO) prepared from powder and supplemented with
$10 \%$ fetal calf serum and $100 \mu \mathrm{g} / \mathrm{ml}$ gentamicin (Gibco, Grand Island, NY). The medium for cell cultivation in suspension also contained $0.2 \%$ pluronic acid (Gibco) to protect cells from mechanical shearing. Stocks of Sf 9 cells were maintained as monolayers in $75-\mathrm{cm}^{2}$ tissue culture flasks and subcultured once a week. Medium was changed every three days.

\section{Production of recombinant baculovirus}

The 1070-bp cDNA encoding the catalytic domain of chicken PARP has been isolated by PstI restriction from the plasmid pTG1.2 (8) and was inserted into the single PstI site present inside the polylinker of the baculovirus transfer vector pVL 1392 (16). An ATG codon was introduced by PCR in such a way that the first amino acids of the recombinant protein were Met Ala Leu Thr Val (the amino acids Met and Ala were added by PCR). The amplified fragment was completely sequenced to ensure that no mutation was introduced by PCR. The resulting recombinant plasmid and the linearized Baculogold ${ }^{\mathrm{TM}}$ baculovirus DNA (Pharmigen, San Diego, CA) were cotransfected into Sf 9 cells according to manufacturer instructions. The recombinant viral plaques were identified by visual screening and several putative recombinant viruses were isolated and identified. The overexpression of the recombinant protein was confirmed by Western blot using an antibody raised against the catalytic domain (8).

\section{Bioreactor system}

The simplified bioreactor system for cell cultivation and protein production consisted of Erlenmeyer flasks $(0.5,3$, and 61$)$ immersed in a water bath at $27^{\circ} \mathrm{C}$ with a reciprocating platform (amplitude of $1 \mathrm{~cm}$ ). To assure proper mixing without foaming, shaker frequency was adjusted from 75 to 90 cycles/ min according to the flask size and cell cul- 
ture volume. The Erlenmeyer flasks were sealed with cotton plugs. The traditional spinner flask systems consisted of 100- and 1,000$\mathrm{ml}$ spinner flasks (Belco, Vineland, $\mathrm{NJ}$ ) and a magnetic stirrer was placed inside an incubator. Temperature was set at $27^{\circ} \mathrm{C}$ and mixing was adjusted with the same criteria as used for the Erlenmeyer system.

\section{Purification of the recombinant PARP catalytic domain}

The polypeptide produced in the Erlenmeyer system was purified using a protocol similar to that described by Giner et al. (7).

\section{Results and Discussion}

The protocol for cell cultivation in Erlenmeyer flasks followed by infection using this same system is outlined in Figure 1. Cultivation was initiated by seeding $4.0 \times 10^{7}$ cells in a 500-ml Erlenmeyer flask containing 100 $\mathrm{ml}$ of medium. After three days, $2.0 \times 10^{8}$ cells were centrifuged at $1,000 \mathrm{~g}$ for $5 \mathrm{~min}$, resuspended in $400 \mathrm{ml}$ of fresh medium, and transferred to 3-1 Erlenmeyer flasks. At the end of two additional days of cultivation, a last cell propagation step was undertaken by centrifuging and resuspending $5.9 \times 10^{8}$ cells in 1.21 of medium placed in a 6-1 Erlenmeyer flask. Within three days, cell density was about $2.4 \times 10^{6}$ cells $/ \mathrm{ml}$ ( $3 \times 10^{9}$ total cells).

Recombinant protein was produced by cell infection with recombinant baculovirus and subsequent cultivation for overexpression of the desired protein. Infection with recombinant baculovirus containing the sequence for the expression of the catalytic domain of PARP was carried out at $27^{\circ} \mathrm{C}$ by recovering the cells by centrifugation and suspending them in the virus stock solution (multiplicity of infection of 5; cell density of $1.0 \times 10^{7}$ cells $/ \mathrm{ml}$ ). After $1 \mathrm{~h}$ of infection, the cell suspension was diluted ten-fold with fresh medium (final cell density of $1.0 \times 10^{6}$ cells/ml). This cell suspension (3 l) was di- vided into three equal fractions that were incubated in three 3-1 Erlenmeyer flasks for final cultivation and protein overexpression. Samples were taken daily from flasks under a sterile hood to allow exchange of air in the head-space. Cells were harvested on the third day after infection and immediately frozen at $-80^{\circ} \mathrm{C}$ until purification of the recombinant protein.

Using Erlenmeyer flasks to cultivate Sf9 cells proved to be more versatile and simpler than using spinner flasks since flasks of different sizes were readily available. Erlenmeyer flasks do not have any impellers or

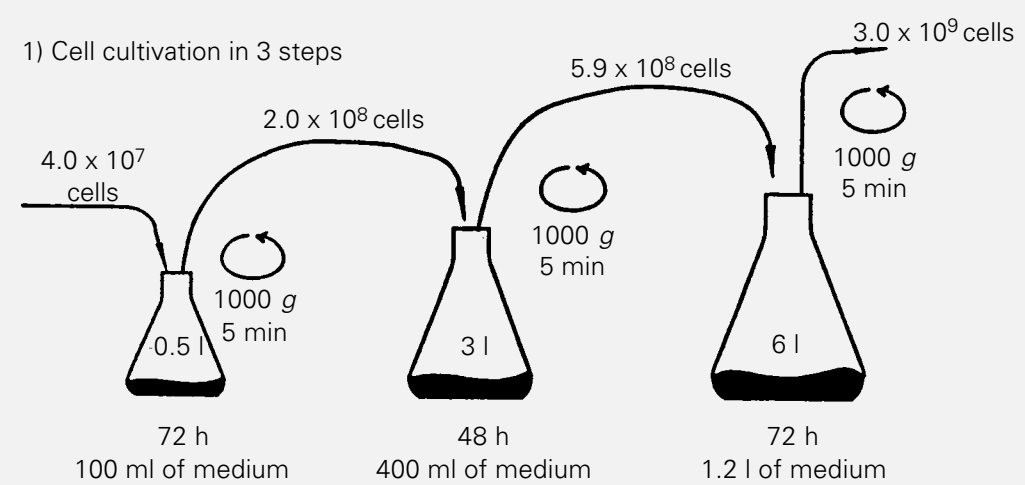

2) Infection (1 h)

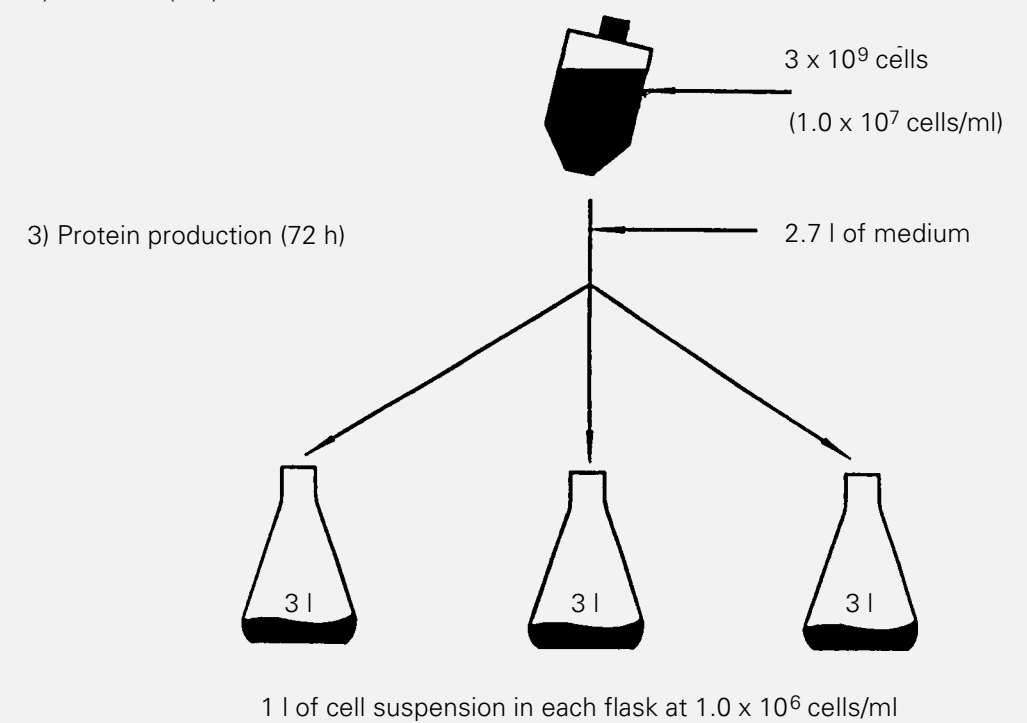

Figure 1 - Schematic outline of the protocol for cell cultivation/infection and protein production in Erlenmeyer flasks. 
other moving parts, thus making washing and, especially, sterilization easier or more efficient. Large-scale processing was facilitated by the possibility of handling large culture volumes in large Erlenmeyer flasks (as much as 31 of culture in a 6-1 flask). In a 1-1 spinner flask, maximum cell culture volume was limited to $400-500 \mathrm{ml}$ since larger volumes required stirring speeds which led to extensive cell damage and death.

Cell growth rates in the Erlenmeyer flasks were higher and more stable than those observed in the spinner flask. The average apparent doubling time (doubling time based on the total number of cells at time zero of the first cultivation step and at the end of the cultivation step immediately before infection) for cells grown in the Erlenmeyer system was $31 \mathrm{~h}$, with a standard deviation of 5 $\mathrm{h}$ (3 runs), while for the spinner flask it was $45 \mathrm{~h}$, with a standard deviation of $19 \mathrm{~h}(6$ runs). Final cell density in Erlenmeyer flasks reached on average $2.7 \times 10^{6}$ cells $/ \mathrm{ml}$ while in spinner flasks cells only grew to densities of about $1.4 \times 10^{6}$ cells. Also, a two-fold larger amount of recombinant polypeptide was produced per cell from cells cultivated in Erlenmeyer flasks compared to cells culti- vated in spinner flasks as determined by SDS-PAGE and by densitometry at $550 \mathrm{~nm}$ (Figure 2).

The recombinant PARP catalytic domain produced in the Erlenmeyer flask system was purified to homogeneity (as indicated by SDS-PAGE) (Figure 3). The protocol used for this purification was a modification of the protocol previously described (7) to purify whole chicken PARP, a 113-kDa protein. This protocol is based on the ability of PARP to bind through its catalytic domain to 3-aminobenzamide, a nicotinamide analogue which is an inhibitor of this enzyme. This affinity purification was carried out as affinity adsorption after lysis of the infected Sf 9 cells and removal of nucleic acids by protamine sulfate precipitation. The modification introduced in this protocol was a change in the ammonium sulfate concentrations used for the two precipitation steps for partial purification (from 30 and $70 \%$ saturation to 50 and $65 \%$ saturation). The objective was to optimize the recovery of the 40$\mathrm{kDa}$ chicken PARP catalytic domain since Simonin et al. (8) used this narrow concentration range when purifying the same polypeptide overproduced in Escherichia coli.
Figure 2 - SDS-PAGE $10.1 \%$ SDS-10\% polyacrylamide, Coomassie blue stained) of whole lysates of Sf9 cells infected with recombinant baculovirus for the large-scale expression of the catalytic domain of chicken PARP (72 h of infection, $10^{5}$ cells/ slot). Lane 1, Molecular mass markers (ß-galactosidase, 116 $\mathrm{kDa}$; phosphorylase b, $94 \mathrm{kDa}$; serum albumin, $67 \mathrm{kDa}$; ovalbumin, $43 \mathrm{kDa}$; carbonic anhydrase, $30 \mathrm{kDa}$; trypsin inhibitor, 20 $\mathrm{kDa})$; lane 2, non-infected Sf9; lane 3, Sf9 cells cultivated in spinner flasks; lanes 4 to 6 , three batches of Sf 9 cells cultivated in Erlenmeyer flasks. The arrow indicates the position of the band corresponding to the recombinant 40-kDa catalytic domain of chicken PARP.

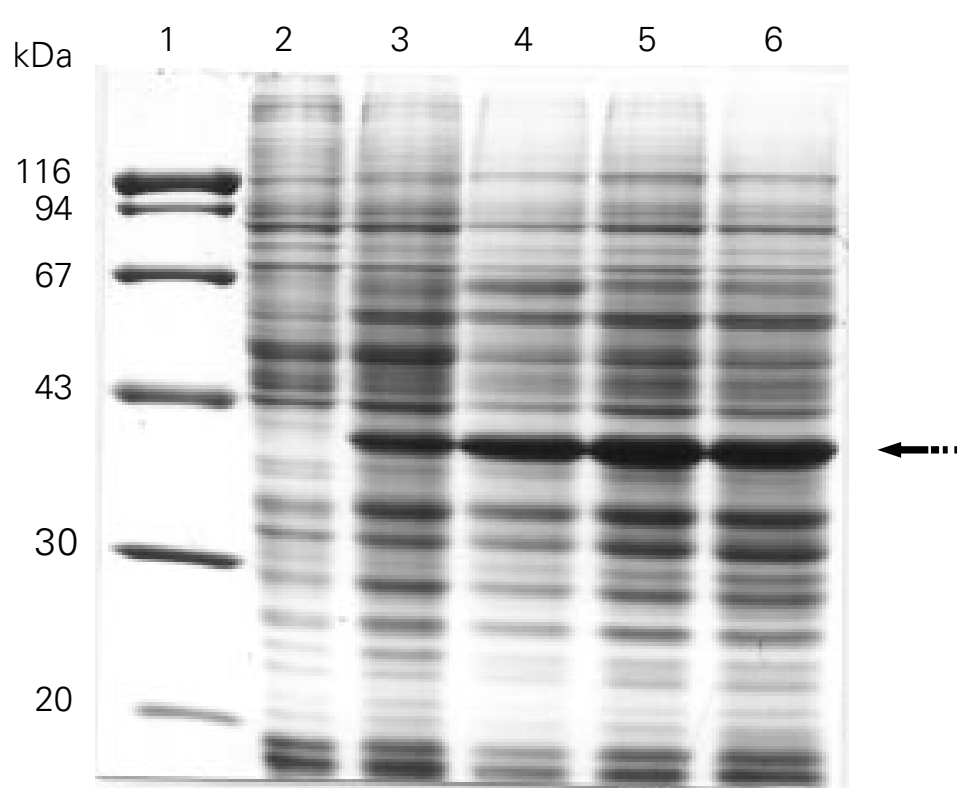


The purified catalytic domain was fully active (data not shown). About $30 \mathrm{mg}$ of protein was produced per liter of cell culture (30 $\mathrm{mg}$ of protein per $10^{9}$ cells). The better performance of the Erlenmeyer flask system compared to the spinner system may be the result of a more constant cultivation temperature and improved aeration. The former may be the main reason for a constant growth rate since temperature fluctuations are known to decrease and even stop cell growth (17). Temperature fluctuations encountered using spinner flasks with magnetic mixers (which always generate some heat) inside incubators were avoided by the use of a water bath. Higher cell density and protein production per cell could be the result of improved aeration in the Erlenmeyer flask since both parameters have been shown to be highly dependent on the aeration rate of the culture (18). Aeration in spinner flasks without oxygen sparging depends on the volume of air in the head-space of the flask and on the degree of mixing. This mixing is severely limited due to high shear forces at the tip of the impellers. However, since impellers are not used in the Erlenmeyer system, these mixing problems are eliminated. Moreover, Erlenmeyer flasks provide a larger surface area per liquid volume and a larger head-space than spinner flasks, favoring improved aeration of the cell culture liquid.

A reviewer has suggested that the determination of the growth curve in the log phase for cells growing in both systems is a better way to compare them. While agreeing with the reviewer, we believe that the apparent doubling time is also a suitable way to compare them regarding our objectives. It accounts for the difference between the growth of the two systems at the log phase and also for the difference due to growth arrest in the lag phase.

Using IC/BEVS, it was possible to grow, infect and produce at high yields a recombinant protein in a simple bioreactor consisting of regular Erlenmeyer flasks and of an ordinary shaker/water bath. Protein overexpression was higher than in systems employing more expensive and cumbersome bioreactors. The low cost, simplicity, and versatility of the system makes this technique feasible for researchers working with equipment available in most biology-related laboratories. The purification protocol produced a homogeneous, pure, and fully active polypeptide suitable for further structure and function studies, e.g., crystallographic analysis, which should enhance our understanding of how this important enzyme functions.

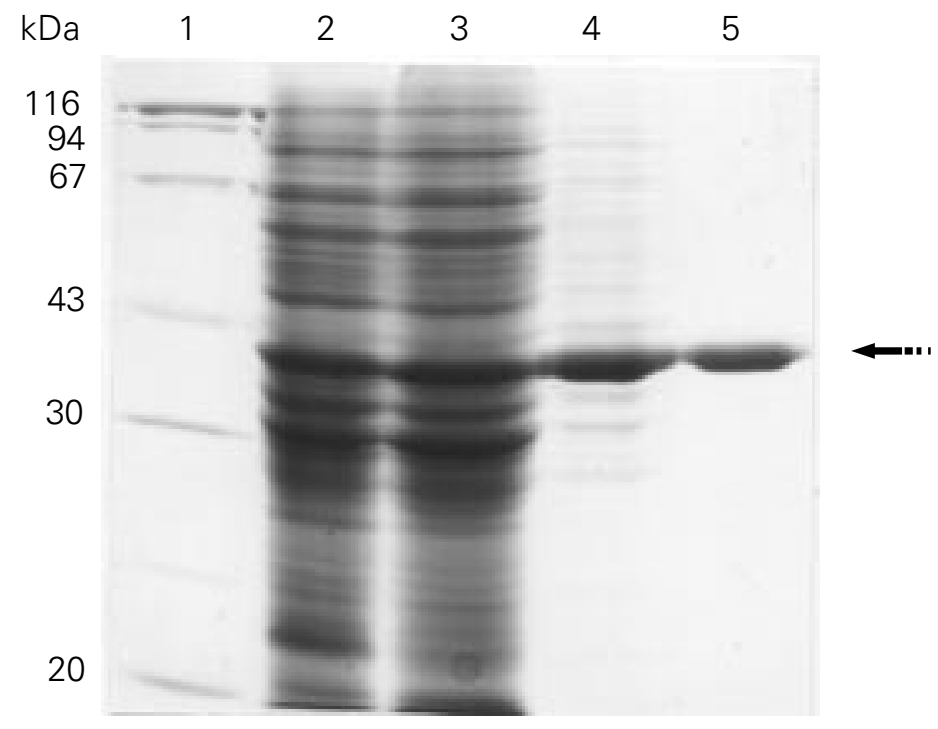

Figure 3 - Monitoring the purification of the recombinant 40-kDa domain of chicken PARP expressed with the baculovirus/insect cell system. Samples at various stages of purification were separated on $0.1 \%$ SDS-10\% polyacrylamide gel (Coomassie blue stained). Lane 1, Molecular mass markers (ß-galactosidase, $116 \mathrm{kDa}$; phosphorylase b, $94 \mathrm{kDa}$; serum albumin, $67 \mathrm{kDa}$; ovalbumin, $43 \mathrm{kDa}$; carbonic anhydrase, $30 \mathrm{kDa}$; trypsin inhibitor, $20 \mathrm{kDa}$ ); lane 2, crude lysate; lane 3 , protamine sulfate precipitation; lane 4, ammonium sulfate precipitation; lane 5, 3aminobenzamide affinity chromatography. The arrow indicates the position of the band correponding to the recombinant 40$k D a$ catalytic domain of chicken PARP. 


\section{References}

1. Althaus FR \& Richter C (1987). ADPribosylation of proteins. Enzymology and biological significance. Molecular Biology, Biochemistry and Biophysics, 37: 1-126.

2. Lautier D, Lagueaux J, Ménard L \& Poirier GC (1993). Molecular and biochemical features of poly(ADP-ribose) metabolism. Molecular and Cellular Biochemistry, 122: 171-193.

3. Satoh MS \& Lindahl T (1992). Role of poly(ADP-ribose) formation in DNA repair. Nature, 356: 356-358.

4. Molinete $M$, Vermeulen $W$, Bürkle $A$, Ménissier-de Murcia J, Küpper J, Hoeijmakers J \& de Murcia G (1993). Overproduction of the poly(ADP-ribose) polymerase DNA-binding domain blocks alkylation-induced DNA repair synthesis in mammalian cells. EMBO Journal, 5: 2109-2117.

5. Masson M, Rolli V, Dantzer F, Trucco C, Schrieber V, Fribourg S, Molinete M, Ruf A, Miranda EA, Niedergang C, Hunting D, Gowans B, Schulz GE, Ménissier-de Murcia J \& de Murcia G (1995). Poly(ADPribose) polymerase: structure-function relationship. Biochimie, 77: 456-461.

6. Suto ML \& Suto MS (1991). Inhibitors of poly(ADP-ribose) polymerase (ADPRP): potential chemotherapeutic agents. Drugs of the Future, 16: 723-739.
7. Giner $H$, Simonin $F$, de Murcia G \& Ménissier-de Murcia J (1992). Overproduction and large-scale purification of the human poly(ADP-ribose) polymerase using a baculovirus expression system. Gene, 114: 279-283.

8. Simonin F, Höfferer L, Panzeter P, Muller S, de Murcia G \& Althaus FR (1993). The carboxy-terminal domain of human poly(ADP-ribose) polymerase: overproduction in Escherichia coli, large scale purification and characterization. Journal of Molecular Biology, 268: 13454-13461.

9. Murhammer DW (1991). Review and patents literature. The use of insect cell cultures for recombinant protein synthesis: Engineering aspects. Applied Biochemistry and Biotechnology, 31: 283-310.

10. Goosen MFA (1992). Large-scale insect cell culture. Current Opinion in Biotechnology, 3: 99-104.

11. Kamen AA, Tom RL, Caron AW, Chavarie C, Massie B \& Archambault J (1991). Culture of insect cells in a helical ribbon impeller bioreactor. Biotechnology and Bioengineering, 38: 619-628.

12. van Lier FLJ, van den End EJ, Gooijer CD, Vlak JM \& Tramper J (1990). Continuous production of baculovirus in a cascade insect-cell reactor. Applied Microbiology and Biotechnology, 33: 43-47.
13. Power J, Greenfield PF, Nielsen L \& Reid $S$ (1992). Modelling the growth and protein production by insect cells following infection by a recombinant baculovirus in suspension culture. Cytotechnology, 9: 149-155.

14. Stavroulakis DA, Kalogerakis N, Behie LA \& latrou K (1991). Kinetic data for the BM5 insect line in repeated-batch suspension culture. Biotechnology, 38: 116-126.

15. Neutra R, Levi B-Z \& Shoham $Y$ (1992) Optimization of protein-production by the baculovirus expression vector system in shake flasks. Applied Microbiology and Biotechnology, 37: 74-78.

16. Luckow VA \& Summers MD (1989). Signals important for high level expression of foreign genes in Autographa californica nuclear polyhedrosis virus expression vectors. Virology, 170: 31-39.

17. O'Reily DR, Miller LK \& Luckow VA (1992). Baculovirus Expression System: A Laboratory Manual. Freeman, New York.

18. Scott RL, Blanchard JH \& Fergusson CHR (1992). Effects of oxygen on recombinant protein production by suspension cultures of Spodoptera frugiperda Sf9 insect cell. Enzyme and Microbial Technology, 14: 798-804. 